ISSN 0206-5657. Вісник Львівського університету. Серія біологічна. 2018. Випуск 78. С. 25-31 Visnyk of the Lviv University. Series Biology. 2018. Issue 78. P. 25-31

\title{
THE FLORA AND VEGETATION OF AUSTRIA AND THE EASTERN ALPS - AND PROBLEMS IN WRITING A MODERN EXCURSION FLORA
}

\author{
M. Fischer \\ Department of Botany and Biodiversity Research, \\ University of Vienna (Austria) \\ 14, Rennweg, 1030 Vienna, Austria \\ e-mail: manfred.a.fischer@univie.ac.at
}

\begin{abstract}
Information about the taxonomic and geographic scope of this Excursion Flora to be published soon and on significant features of vegetation and flora of this region is provided. Some characteristic endemic taxa are mentioned. - Problems of writing an excursion Flora are discussed with focus on hints for improving keys in order to produce a user-friendly book.
\end{abstract}

Keywords: flora, Austria, Eastern Alps

\section{The Excursion Flora}

Austria comprises more than half of the Eastern Alps and, additionally, part of the Bohemian Massiv and the westernmost part of the Pannonian basin and hillsides. The Eastern Alps extend from the Rhine valley in eastern Switzerland (Grisons) to NW. Slovenia, covering the alpine regions of Northern Italy and most of Austria. This excursion Flora to come will treat ca 790 genera and 4050 species (including subspecies) of vascular plants and also the Characeae.

This Excursion Flora in progress (Fischer \& al. in prep., see also Fischer 2018), written with the help of two excellent amateur botanists and to be published approximately next year, is the fourth and enlarged edition of the Excursion Flora for Austria (Adler \& al. 1994, Fischer $\&$ al. 2008). Besides the keys to families, genera, species, and subspecies, the book, comprising two volumes, covers several general chapters with topics as follows: Principles of taxonomy including phylogenetic molecular taxonomy, nomenclature, on plant morphology together with an explanation of all the phytographic (descriptive) terminology, a chapter on ecomorphology (i. e. life forms, adaptational vegetative structures, pollination, seed dispersal etc.), flower scents, phenology, chorology (phytochoria, endemics), flora statistics, floristic mapping; habitat ecology, vegetation ecology (including coenology and syntaxonomy), altitudinal belts, and a survey of the vegetation types of Austria including a key for determining the syntaxa; nature conservancy and national parks and other nature reserves; recent changes of vegetation with emphasis on floristic shifts in the high mountains; neophytes and their impact on flora and vegetation; floristic peculiarities of the different regions; history of floristic research; advice to the user for collecting and herbarizing; finally a survey of the accepted vascular plant system - a modification of the APG system with focus on evolutionary classification (Willner \& al. 2014) - with reference to other systems. The appendix includes a glossary of the technical terms and the meaning of the epithets and a combined register (index) of scientific plant names and of their German, Italian, Romansh (Rumantsch Grischun in Grisons [Switzerland]) and Slovenian equivalents. In the key, difficult structures mentioned in the text are accompanied by small drawings; and in the general volume several species characteristic for the region are shown as full plant drawings with details.

Keys lead to the families, within the families to the genera and within them to the species and subspecies. Short family characteristics are provided, the generic descriptions being included in the keys to genera. Genus names are given not only in Latin and German but also in Rumantsch Grischun, Italian and Slovenian.

(C) Fischer M., 2018 
For all species and subspecies broad information is provided, though in a short and concise way: At first, of course, on specific traits in addition to the characters used in the keys, further data concern plant height, life-form, flowering time, habitats, altitudinal range, and frequency of occurrence within the habitat range. Distributional information is presented with regard to of political regions; in species or subspecies of local distribution, localities like mountain ranges are mentioned in brackets. The floristic status of non-native taxa is specified (archaeophytes, neophytes, i.e. naturalized aliens or casuals); important cultivated taxa are included in the keys, especially those escaping more or less frequently. The external distribution range and/or the chorotype including the type of endemism are stated. Then, the conservational status and the degree of threat are given by mentioning their Red List status for all countries involved, and a sign für legal protection is provided. For species of ethnobotanic interest, their plant use is briefly summarised, including toxicity (by a symbol); taxonomical problems are discussed and, in taxonomically difficult taxa, literature references are provided. Species and subspecies which are difficult to identify are supplied with two special symbols to alert the user: whether the troubles come from complicated characters or because the taxa have not been adequately studied yet. This is to save unexperienced users from despair.

Nomenclature is treated thoroughly: All important synonyms used within the last 50 years and in contemporary floras of neighbouring countries are mentioned. In many cases (if useful), taxonyms are given, i. e. the reference is provided to the book where the synonym is used as the acepted name, irrespective if this synonym is nomenclaturally legitimate or not (Fischer 2015). The nomenclatural authors, however, of all scientific taxon names are deliberately omitted because they are of no value for the exact determination of the taxon. On the contrary, they are misleading because almost all users (some professional botanists included) fail to recognise their meaning, as they might think that the name of these nomenclatural authorities refers to the circumscription of the taxon which of course is not the case (see Fischer 2000, 2010, 2011, 2014, 2015, Fischer \& Willner 2010). (Actually, merely full nomenclatural author citations - including indication of the protologue - are useful and necessary for that taxonomist only who produces new taxa or changes the scope (circumscription) of the taxon, in order to establish the legitimate name.) syllable.

The correct pronunciation of the Latin taxon names is indicated by underlining the stressed

In several cases when the species is likely to be confused with similar species, we add annotations explaining the most striking differences.

\section{Vegetation and Flora of Austria and the rest of the Eastern Alps}

Significant features of the vegetation of the Eastern Alps with Austria are the subcontinental Pannonian lowland vegetation in the northeasternmost parts of Austria bordering Moravia, Slovakia and Hungary, the siliceous medium highlands in northern Austria (up to ca. $100 \mathrm{~m}$ a. s.), the southeastern hillsides with some illyric influence, and, mainly, the vast Alps, comprising predominantly calcareous mountains in the N. (mainly within Austria; The highest peaks being Dachstein (2995) and Zugspitze (2962 m a. s.). In the South, mainly within Italy and Slovenia, the highest pekas are Marmolada (3343) Triglav (2863 m a. s.), and in the large, predominently siliceous Central Alps (mainly within Austria, partly in Grisons and in Italy) the highest peaks are Großglockner (3798), Piz Bernina (4049) and Adamello (3554 m a. s.).

Significant natural zonal vegetation types are dry oak forests (Quercus petraea, Qu. cerris, Qu. pubescens) in the Pannonian region, central European beech forests (Fagus sylvatica) in the montane belt of the Northern and Southern Exterior Alps, dominating spruce forests (strongly 
enhanced by human influence: Picea abies is widely planted for timber) in the Central Alps. A conspicuous vegetation factor is the differentiation along the altitudinal gradient: Oak-hornbeam forests (Quercus petraea, Carpinus betulus) in the lower mountains, beech dominated forests in the middle and upper mountains (with Abies alba, Picea abies, Acer pseudoplatanus), subalpine forest and scrub vegetation near the timberline (Picea abies, Larix decidua, Pinus cembra, P. mugo, Alnus alnobetulus) including ericaceous dwarf-shrub communities (Rhododendron ferrugineum and Rh. hirsutum, Vaccinium myrtillus, M. vitis-idaea, V. uliginosum subsp. gaultherioides, Arctostaphylos uva-ursi, A. alpinus), significantly differentiated by different intensity of soil acidity; alpine communities (Kalmia [Loiseleuria] procumbens, Carex curvula; C. firma, C. sempervirens, Dryas octopetala, Salix herbacea) also strongy differentiated by calcareous vs. silicous bedrocks. Another important ecological gradient is due to the climatic difference between the Exterior Alps with suboceanic climate and the Interior Alps with subcontinental climate (no Fagus sylvatica!).

Azonal vegetation includes riverside vegetation mainly along big rivers like the Danube (National Park Donauauen), Inn and Mur, strongly diminished and threatened nowadays by electricity production; local salt steppe vegetation in the Pannonian Basin (National Park Neusiedler See and Seewinkel in Burgenland); some raised Sphagnum bogs (e.g. Drosera rotundifolia, Andromeda polifolia); different types of montane and alpine rock vegetation; local ophiolithic (serpentinic) vegetation (e.g. with Paragymnopteris [Notholaena] marantae, Asplenium cuneifolium, Noccaea [Thlaspi] goesingensis). Remarkable are relic forests of Pinus nigra subsp. nigra on dolomitic bedrocks at the north-eastern margin of the Alps (near Vienna) and in the Karawanken range in S. Carinthia.

Anthropogenic vegetation dominates in lower altitudes: fields with main crops, mainly wheat (Triticum aestivum) and maize (Zea mays), also barley (Hordeum vulgare, H. distichon), potato (Solanum tuberosum), rye (Secale cereale), sugar beet (Beta vulgaris cv. altssima), locally also oil pumpkin (Cucurbita pepo cv. styriaca), rapeseed (Brassica napus), soybean (Glycine max), sunflower (Helianthus annuus), strawberries (Fragaria ananassa) etc. There are also vineyards producing grapes (Vitis vinifera) above all for wine production and orchards with apples (Malus domestica), apricots (Prunus armeniaca), elderberries (Sambus nigra) etc. Mainly in the Alps (montane and subalpine belts) there are vast meadows and pastures for cattle breeding and milk production.

Endemism. The flora of the Eastern Alps includes several endemics, particularly in the alpine, but also in the montane belt. There are as many as five endemic genera: Rhizobotrya (sister to Kernera; Cruciferae), Physoplexis (close to Phyteuma, Campanulaceae), Psilathera and Sesleriella (both close to Sesleria, Poaceae), and Hladnikia (Apiaceae). Especially the genera Campanula, Gentiana, Primula, Saxifraga are rich in endemic species and subspecies. The endemics are centered in (a) the S. Alps (at the border of Austria to Italy and Slovenia) and in (b) the NE. Calcareous Alps in Austria, which are regions that provided refuge during the last (Würm) glaciation period. However, some endemics are located in (c) the Central Alps which were covered by a huge ice sheet during the Würm glaciation. (For more information see Fischer 2018 and Staudinger \& al. 2009.)

Some examples for (a) are: Allium insubricum, Cytisus emeriflorus, Daphne petraea, Campanula morettiana, C. petraea, Carex baldensis, Euphrasia tricuspidata, Galium montis-arerae, Gentiana brentae, Hladnikia pastinacifolia, Leucanthemum lithopolitanicum, Linaria tonzigii, Minuartia glaucovirens, Nigritella buschmanniae, Pedicularis hoermanniana, Phyteuma hedraianthifolium, Pinguicula poldinii, Primula carniolica, P. glaucescens, P. spectabilis, Pseu- 
dostellaria europaea, Ranunculus bilobus, Sanguisorba dodecandra, Saxifraga arachnoidea, S. presolanensis, S. tombeanensis, Viola culminis, Wulfenia carinthiaca subsp. carinthiaca; - for (b): Achillea clusiana, Callianthemum anemonoides, Campanula pulla, Euphorbia saxatilis, Nigritella nigra subsp. austriaca, Noccaea (Thlaspi) crantzii, Pedicularis portenschlagii, Primula clusiana, Soldanella austriaca; - for (c): Braya alpina, Cochlearia excelsa, Saxifraga blepharophylla, Sempervivum pittonii, S. stiriacum, Valeriana celtica subsp. celtica. - Doronicum cataractarum, Moehringia diversifolia and Saxifraga paradoxa are local endemic to the southeasternmost edge of the Alps (on mount Koralpe) who probably could have survived glaciation here. - There is even one local endemic in the moist vegetation in the Austrian Pannonian region: Cochlearia macrorrhiza (close to C. pyrenaica).

\section{Writing a floral key is a demanding job}

Writing a flora seems to be an easy job as it seems to consist mainly of the compilation of data presented in other books. Anybody trying to write a key will soon understand that this idea is quite wrong. Every plant lover knows floras and keys that cause anger and despair because it seems impossible to reach the correct identification. Is it the plants that are to blame? Even some professional botanists think so, nevertheless they are not correct. Or is it rather the botanist, the author of the key? - The editor of a key and of a Flora must combine several abilities: He or she has to know not only as many taxa as possible but has to have also a sound knowledge of several fields of botany: mainly morphology, taxonomy, ecology and plant geography. Even more important are an excellent command of language and the inevitable competence of a good teacher, i.e. to be able to empathize with people of limited botanical and floristic knowledge. It is essential that a key is user-friendly as it should work for users who are not botanists and are not yet familiar with the naming of plants.

Two main dangers are obvious: (1) Producing a key, the author must not try to use primarily the taxonomically relevant characters because they are often difficult to analyse. A key is no taxonomic survey. A key, instead, has to use key characters which are easily to recognise. If necessary, a taxonomic scheme showing the affinities should be kept separate. (2) Taxonomists tend to idealize their taxa, i.e. they neglect variation. For a good key, however, indication of the variation amplitude of all characters is essential.

(3) A rather common shortcoming of identification keys is bad or almost absent comparability. Closely related or similar species (the same is true for genera) must be fully comparable, that means, all characters (plant parts, organs) used to indicate differential states are to be mentioned in all taxa of the relevant group, ideally of the whole genus and described in the same way (a description of pinnate leaves like "9 leaflets" vs. "6 pairs of leaflets" is not advisible).

Some key-writers, by trying to present a vivid picture of the species, concentrate on conspicuous traits but neglect those needed for comparison. In this way, two species are characterized by their most striking characters only: "leaves linear to lanceolate, flowers big; ovary pubescent; seeds numerous" vs. "leaves all basal; flowers yellow, scented; ovary 3-locular; seeds globose". - Can you understand that the user of this key gets angry? Needless to mention that size should be expressed by the metric system and wordings like "of cherry-size" are unhelpful (to say the least). The reader can never know and hardly guess whether the omitted characters are the same, absent, variable or unexplored.

If a character exhibits no difference between the relevant taxa, this fact should also made clear. Such characters in common should be mentioned in the previous step, in order to avoid useless (and confusing) repetitions. All the species of a group (species group or section or even genus) should be comparable by all their characters. In many keys this is not possible because only some 
striking differences are selected. This makes identification unnecessarily troublesome. Another important feature of a user-friendly key is the strict separation of (a) good, discriminative characters ("absolute differences", not "usually"!) from (b) overlapping characters. It is important also to stick to the same sequence of the characters within both groups. The following fictive example might illustrate the principles of such a "diacritical" key.

1 Petals 3-4; stem villous; seed globose, dark brown; plant stinking like the devil, height 80-120 $\mathrm{cm}$. - Rhizome without tuberous parts; stem terete; leaves opposite, sessile, lamina usually orbiculate; corolla usually bright purple; style $2 \mathrm{~mm}$ long; fruit glabrous. [Dates on autecology, habitats, distribution etc. following.] - (C. diabolica; C. diarrhoeica) Devil's s. / C. infernalis - Petals 5-7; stem glabrous or pubescent; seed elliptical, yellow; plant smelling heavenly, height not more than $70 \mathrm{~cm}$. - Stem terete to slightly quadrangular .

2 Stem glabrous; style ca. $2 \mathrm{~mm}$ long; all leaves opposite, - with a 0,5-2 cm long petiole. Rhizome with thickenings like a string of pearls; leave-blade ovate to lanceolate; corolla bright to dark purple; fruit glabrous. [etc.]

Glabrous s. / C. glaberrima - Stem pubescent; style ca. $4 \mathrm{~mm}$ long; at least upper leaves alternate, - usually almost sessile. Rhizome usually without any thickenings; leave-blade lanceolate to linear-lanceolate; corolla usually dark purple; fruit glabrous to subhirsute. [etc.]-(C. vulgaris) Velvet s. /

\section{C. velutina}

The characters before the long dash are those designated (a) above, we call them "diacritical", they are arranged as to their importance and easiness of recognition. They are kept strictly parallel, also in their wording. The indument of the stem is just indicated for parallelism, otherwise such variable characters are omitted because explained anyway later in the course of the key. - The characters after the long dash ("completive characters") are arranged in "phytographic" sequence (i.e. from the root upwards), they include variable characters, "usual" characters and characters common to the taxa in the following steps of the key (in order to prevent repetitions).

(4) Logic, precise and consistent terminology is imperative. It should be in accordance with scientific morphology. So, the petiole is no appendage of the leaf, but part of it; leaf and leafblade must be carefully distingished etc. Terms with variable meaning like "lanceolate" (three meanings! - STEARN 1992) or "denticulate" (different definitions in different books) must be explained and strictly followed. The unequivocal meaning of descriptions has to be considered meticulously:

Just one simple example: How do you understand the following alternative?

"With black glandular hairs" vs. "no black glandular hairs present"? Two meanings are possible: the second alternative means (a) that there are non black glandular hairs, but possibly white glandular hairs present; (b) no glandular hairs at all are present. In case (a) "no" refers to "black", in (b) "no" refers to "glandular".

A wide-spread nuisance is: "4-6 mm long" vs. "up to $12 \mathrm{~mm}$ long". This is, if course, no logic or intelligent alternative, because the length of $5 \mathrm{~mm}$ fits as well to "up to $6 \mathrm{~mm}$ ". - What is the meaning of " $3 \times$ longer"? Is this $3 \times$ as long or $4 \times$ as long? Logically (mathematically) $1 \times$ longer is longer by $100 \%$, i.e. double as long, $2 \times$ longer is $3 \times$ as long and so on.

(5) Some friends of flowers and plants would say: "I am too stupid to use keys, I prefer pictures". Is such a sceptical attitude justfied? Is the low quality of several keys responsible for that opinion? Is it not possible to improve the quality of keys? Is it true that illustrated field guides are more effective in plant identification than traditional Floras with keys and no colour photographs? - Let us put a critical view to all those books full of beautiful photographs of plant 
species. Do they really enable identification? (a) Most photos show flowers or inflorescences only, but no vegetative parts which are generally essential; (b) taxonomically important details are often not shown, e.g. the involucrum in Compositae (the heads simply seen from above all look almost alike!) and the indumentum; (c) variation is neglected, the specimen photographed does not tell anything about the variation of the species; (d) for untrained persons it is not easy to "read" pictures, i.e. to correspond them to nature; (e) the mere name of a plant is not its most unimportant feature. So, picture Floras often lead to misidentification.

My thanks are due to Margaret Erős for linguistic improvements.

\section{REFERENCES}

1. Addler W., Oswald K., \& Fischer R., 1994: Exkursionsflora von Österreich. Bestimmungsbuch für alle in Östereich wildwachsenden sowie die wichtigsten kultivierten Gefäßpflanzen (Farnpflanzen und Samenpflanzen) mit Angaben über ihre Ökologie und Verbreitung. Stuttgart \& Vienna: Ulmer Verlag.

2. Fischer M. A., 2000: Brauch und Missbrauch der nomenklatorischen Autorennamen. Florae Austriae Novitates 6: 9-46.

3. Fischer M. A., 2010: Do plant identification keys enable identification? Phytologia Balcanica (Sofia), 16 (2): 175-185.

4. Fischer M. A., 2014: Wissenschaftliche Pflanzennamen und nomenklatorische Autorenbezeichnungen. In: Rottensteiner W. K. (Ed.): Exkursionsflora für Istrien; p. 17-20. Klagenfurt: Naturwissensch. Ver. Kärnten.

5. Fischer M. A., 2015: Was ist ein Taxonym? Mit einem neuerlichen Blick auf die nomenklatorischen Autorennamen und deren missverstandene Rolle sowie auf die Nomenklaturregeln im Allgemeinen. Neilreichia, 7: 195-229.

6. Fischer M. A., 2018: Towards an Excursion Flora for Austria and all the Eastern Alps. Botanica Serbica, 42 (1): 5-33 (Festschrift Stefan Stevanović).

7. Fischer M. A. \&. Willner W., 2010: Aktuelles über das Projekt „Flora von Österreich“: Prinzipien, Methodologie und Wiki-Internet-Flora. Ansprüche wissenschaftlichen Florenschreibens. - Sauteria (Dorfbeuern im Land Salzburg), 18: 101-186.

8. Fischer M. A., Oswald K. \& Adler W., 2008: Exkursionsflora für Österreich, Liechtenstein und Südtirol. 3. Auflage. - Biologiezentrum der Oberösterreichischen Landesmuseen, Linz.

9. Fischer M. A., Oswald K. \& Adler W., in prep.: Exkursionsflora für Österreich und die gesamten Ostalpen. 4. Auflage. Linz: Biologiezentrum der Oberösterreichischen Landesmuseen.

10. Staudinger M., Stohr O., Essl F., Schratt-Ehrendorfer L., Niklfeld H., \& Niklfeld Gutermann W., 2009: Gefäßpflanzen. In: Rabitsch W. \& EssL F. (Ed.): Endemiten. Kostbarkeiten in Österreichs Pflanzen- und Tierwelt; p. 64-267. Klagenfurt: Naturwiss. Verein für Kärnten; \& Wien: Umweltbundesamt GmbH. 924 p.

11. Stearn W.T. 1992: Botanical Latin. History, Grammar, Syntax, Terminology and Vocabulary. $4^{\text {th }}$ ed. Newton Abbot, Devon: David \& Charles Ltd.

12. Willner W., Hulber K. \& Fischer M. A., 2014: Return of the grades: towards objectivity in evolutionary classification. Preslia, 86: 233-243. 


\title{
ФЛОРА І РОСЛИННІСТЬ АВСТРІЇ ТА СХІДНИХ АЛЬП І ПРОБЛЕМИ ОПИСУ СУЧАСНОЇ ЕКСКУРСІЙНОЇ ФЛОРИ
}

\author{
M. Фішер
}

\author{
Кафедра ботаніки і дослідження біорізноманіття \\ Віденський університет \\ Реннвег, 14, Відень 1030, Австрія \\ e-mail: manfred.a.fischer@univie.ac.at
}

\begin{abstract}
У даній роботі надано інформацію про підготовку четвертого розширеного видання Excursion Flora, яка буде охоплювати територію Східних Альп у межах не лише Австрії, а й відповідних частин Швейцарії, Північної Італії та Словенії. Описано зміст книги, яка буде складатися 3 двох томів. Крім ключів для визначення родин, родів, видів і підвидів, Excursion Flora охоплює кілька загальних розділів: принципи систематики, включаючи філогенетичну молекулярну таксономію, номенклатуру, морфологію рослин разом із поясненням фітографічної термінології, розділи 3 екоморфології, фенології, хорології (фітохорія, ендемізм), флористичної статистики, флористичного картування, екології оселищ, екології рослинності (включаючи ценологію та синтаксономію), характеристики висотних поясів, а також огляд особливостей флори і рослинності регіону, типів рослинності Австрії з ключами для визначення синтаксонів, проблем охорони природи, оцінкою недавніх змін рослинності з акцентом на флористичних зрушеннях у високих горах, неофітах і їхнім впливом на флору й рослинність, поради користувачу для збору та гербаризації. I нарешті - огляд історії флористичних досліджень і прийнятої системи видів судинних рослин - модифікації системи APG з акцентом на еволюційну класифікацію та 3 посиланням на інші системи.

Додаток містить словник технічних термінів і значення епітетів, а також комбінований індекс наукових назв рослин та їхніх німецьких, італійських, ретороманських і словенських еквівалентів. У ключах складні структури, згадані в тексті, супроводжуються невеликими рисунками, а в загальному томі для кількох видів, характерних для регіону, подано повні рисунки рослин із деталями. Згадано деякі характерні ендемічні таксони.

В обговоренні проблем опису екскурсійної флори зроблено наголос на покращенні ключів у книзі, щоб зробити їі якомога зручнішою для користувача.
\end{abstract}

Ключові слова: флора, Австрія, Східні Альпи 